\title{
KERAGAAN RANTAI PASOK TEPUNG KELAPA PT. UNICOTIN DI SULAWESI UTARA
}

\section{COCONUT FLOUR SUPPLY CHAIN PERFORMANCE AT PT. UNICOTIN IN NORTH SULAWESI}

\author{
Monalisa Anny Luntungan ${ }^{(1)}$, Agnes Estephina Loho ${ }^{(2)}$, Rine Kaunang_ ${ }^{(2)}$
}

1) Mahasiswa Program Studi Agribisnis, Fakultas Pertanian, Universitas Sam Ratulangi, Manado

2) Dosen Program Studi Agribisnis, Fakultas Pertanian, Universitas Sam Ratulangi, Manado

*Penulis untuk korespondensi: luntunganmonalisa27@gmail.com

\begin{abstract}
This study aims to describe the supply chain performance of coconut flour at PT. UNICOTIN by focusing on supply chain flow. This research was conducted from December 2019 to September 2020 at PT. UNICOTIN, North Sulawesi. The research method used in this research is case study method. The data used in this study are primary data and secondary data. The data analysis technique used in this research is descriptive analysis method to describe the supply chain performance at PT. UNICOTIN. Supply chain actors are (a) Suppliers of coconut raw materials including farmers, concurrently farmers, collectors, (b) PT. UNICOTIN in Airmadidi, (c) Head office of PT. UNICOTIN in Jakarta, (d) large importers in Germany, Holland, England, Poland, Egypt, Russia and China, and small numbers of other importers who have their respective roles. The supply chain flow consists of information flow starting from the need for coconut flour from the importer to the Jakarta Head Office, the flow of products starting from the supply of raw coconut materials from the supplier, and financial flows in the form of payments from the importer to the Jakarta head office.
\end{abstract}

Keywords: supply chain; coconut flour

\begin{abstract}
ABSTRAK
Penelitian ini bertujuan untuk mendeskripsikan keragaan rantai pasok tepung kelapa di PT. UNICOTIN dengan memfokuskan pada aliran rantai pasok. Penelitian ini dilaksanakan dari bulan Desember 2019 sampai bulan September 2020 di PT. UNICOTIN, Sulawesi Utara. Metode penelitian yang digunakan dalam penelitian ini adalah studi kasus. Data yang digunakan dalam penelitian ini adalah data primer dan data sekunder. Teknik analisis data dalam penelitian ini menggunakan metode analisis deskriptif untuk mendeskripsikan keragaan rantai pasok pada PT. UNICOTIN. Pelaku rantai pasok adalah (a) Pemasok bahan baku kelapa meliputi petani, petani yang merangkap, pedagang pengumpul, (b) PT. UNICOTIN di Airmadidi, (c) Kantor pusat PT. UNICOTIN di Jakarta, (d) importir besar di Jerman, Belanda, Inggris, Polandia, Mesir, Rusia dan Cina, dan importir lainnya dalam jumlah kecil yang memiliki perannya masing-masing. Aliran rantai pasok terdiri dari aliran informasi yang berawal dari kebutuhan tepung kelapa dari importir ke Kantor Pusat Jakarta, aliran produk yang diawali dari persediaan bahan baku kelapa dari pemasok, dan aliran finansial yang berupa pembayaran Importir ke kantor pusat Jakarta.
\end{abstract}

Kata kunci : rantai pasok; tepung kelapa 


\section{PENDAHULUAN}

\section{Latar Belakang}

Provinsi Sulawesi Utara mempunyai potensi sumber daya alam yang besar pada sektor pertanian sehingga sektor Pertanian sangat berperan penting terhadap perekonomian di Sulawesi Utara. Salah salah satu tanaman perkebunan yang mendominasi di Sulawesi Utara adalah tanaman kelapa sehingga mendapat julukan daerah nyiur melambai. Luas areal dan produksi tanaman kelapa disajikan pada Tabel 1.

Tabel 1. Luas Areal dan Produksi Kelapa Sulawesi Utara Tahun

\begin{tabular}{|c|c|c|}
\hline \multirow{2}{*}{ Tahun } & \multicolumn{2}{|c|}{ Perkebunan Rakyat } \\
\hline & Luas / Area (Ha) & Produksi (Ton) \\
\hline 2016 & 267.155 & 240.505 \\
\hline 2017 & 267.034 & 241.902 \\
\hline 2018 & 266.931 & 242.281 \\
\hline
\end{tabular}

Sumber: Badan Pusat Statistika Sulawesi Utara, 2018

Tanaman kelapa sangat bermanfaat untuk kesehatan dan dapat diolah menjadi berbagai produk olahan, baik untuk konsumsi memenuhi kebutuhan dalam negeri maupun luar negeri. Bahkan produk turunan kelapa sudah dimanfaatkan oleh produsen untuk tujuan ekspor sehingga memberikan kontribusi yang cukup besar untuk devisa Sulawesi Utara. Beberapa olahan buah kelapa berupa tepung kelapa, minyak goreng, virgin coconut oil, santan, bahan baku kue kelapa, dan masih banyak lagi olahan dari kelapa (Anonim, 2013). Di Sulawesi Utara terdapat PT. UNICOTIN merupakan pabrik tepung kelapa yang telah beroperasi sejak tahun 2007. Sebagain besar produk yang diproduksi dipasarkan ke Mancanegara.

PT. UNICOTIN merupakan salah satu dari 9 perusahaan tepung kelapa di Sulawesi Utara yang terletak di Kelurahan Sarongsong Satu Kecamatan Airmadidi Kabupaten Minahasa Utara. Volume dan nilai ekspor perusahaan ke enam Negara importir terbesar ini disajikan pada Tabel 2.

\begin{tabular}{|c|c|c|}
\hline Negara Tujuan & $\begin{array}{l}\text { Volume } \\
(\mathrm{Kg})\end{array}$ & $\begin{array}{l}\text { Nilai } \\
\text { (US S) }\end{array}$ \\
\hline $1 \quad$ Rusia & $4.496 .975,00$ & $5.182 .335,11$ \\
\hline 2 Jerman & $3.437 .307,00$ & $4.448 .095,30$ \\
\hline 3 China & $1.667 .556,29$ & $2.033 .482,79$ \\
\hline 4 Belanda & $1.505 .433,60$ & $1.987 .071,85$ \\
\hline 5 Selandia Baru & $1.028 .423,80$ & $1.462 .716,52$ \\
\hline 6 Negara lainnya & $5.397 .007,40$ & $6.705 .137,53$ \\
\hline TOTAL & $17.532 .703,09$ & $21.818 .839,10$ \\
\hline
\end{tabular}

Keberhasilan perusahaan ini dalam usaha dalam mengoperasikan jalannya perusahan membutuhkan pengelolaan yang efisien agar dapat memperoleh keuntungan yang maksimum. Salah satu cara dalam pengelolaan yaitu dengan mengetahui rantai pasok. Oleh sebab itu diperlukan kajian keragaan rantai pasok.

\section{Pengertian Rantai Pasok}

Supply chain atau dapat diterjemahkan sebagai rantai pasok merupakan rangkaian hubungan antar perusahaan atau aktivitas yang melaksanakan penyaluran pasokan barang atau jasa dari tempat asal sampai ke tempat pembeli atau pelanggan. Selanjutnya, menurut Assauri, (2011) Supply chain menyangkut hubungan yang terus-menerus berupa aliran barang, uang dan informasi. Barang umumnya mengalir hulu ke hilir, uang mengalir dari hilir ke hulu, sedangkan informasi mengalir baik dari hulu ke hilir maupun hilir ke hulu. Levi, \& S. Levi (2003) mendefinisikan Manajemen Rantai Pasok sebagai suatu pendekatan yang digunakan untuk mencapai pengintegrasian yang efisien dari pemasok, pabrikan, distributor, pengecer, dan pelanggan. Artinya barang dapat diproduksi dalam jumlah yang tepat, pada saat yang tepat, dan pada tempat yang tepat dengan tujuan mencapai suatu biaya dari sistem secara keseluruhan yang minimum dan juga mencapai service level yang diinginkan.

\section{Komponen Rantai Pasok}

Porter (2004) terdapat 3 komponen rantai pasok, yaitu:

1. Rantai Pasok Hulu (Upstream)

Bagian hulu (upstream) rantai pasok meliputi aktivitas usaha tani dan pengolahan atau penanganan pasca panen.

2. Rantai Pasok Internal (Management)

Bagian dari rantai pasok internal meliputi semua proses pemasukan barang ke gudang yang digunakan dalam mentransformasikan masukan dari para penyalur ke dalam keluaran organisasi itu.

3. Rantai Pasok Hilir (Downstream)

Rantai pasok hilir (downstream) meliputi aktivitas distribusi pengiriman produk kepada pelanggan terakhir,

kegiatannya adalah transportasi, penyimpanan, pengepakan, sortasi, dan kegiatan lainnya. 


\section{Rumusan Masalah}

Adapun rumusan masalah dari penelitian ini adalah bagaimana keragaan rantai pasok tepung kelapa PT. UNICOTIN di Minahasa Utara?

\section{Tujuan Penelitian}

Penulisan ini bertujuan untuk mendeskripsikan keragaan rantai pasok tepung kelapa di PT. UNICOTIN dengan memfokuskan pada aliran rantai pasok.

\section{Manfaat Penelitian}

Adapun manfaat dari penelitian ini yaitu:

1. Menambah pengetahuan Penulis tentang keragaan rantai pasok dengan kasus pabrik tepung kelapa PT. UNICOTIN

2. Menjadi informasi awal bagi peneliti lain yang berminat untuk meneliti di perusahaan PT. UNICOTIN

\section{METODE PENELITIAN}

\section{Waktu dan Tempat Penelitian}

Penelitian ini dilaksanakan sejak persiapan hingga penulisan yaitu bulan Desember 2019 sampai bulan September 2020 dan berlokasi di PT. UNICOTIN, Sulawesi Utara.

\section{Metode Pengumpulan Data}

Metode penelitian yang digunakan dalam penelitian ini adalah studi kasus. Sumber data dalam penelitian ini terbagi atas dua sumber yaitu data primer dan data sekunder. Data primer diperoleh dari perusahaan. Data sekunder bersumber dari Perusahaan, dinas perkebunan, Disperindag dan BPS SULUT. Teknik penarikan responden yang digunakan dalam penelitian ini adalah Snowball Sampling.

\section{Konsep Pengukuran Variabel}

Fokus penelitian ini aliran yang terjadi sepanjang rantai pasok berupa pengelolaan aliran produk, aliran finansial dan aliran informasi dari rantai pasok tepung kelapa pada PT. UNICOTIN, pelaku rantai pasok dan peran pelaku rantai pasok. Adapun variabel digunakan dalam penelitian ini adalah sebagai berikut:

\section{Pelaku rantai pasok}
a. Pemasok bahan baku (supplier)
b. Pabrik (manufacturer)
c. Distributor (wholsalers)
d. Pengecer (retailer)
e. Konsumen (customer)

\section{Peran Pelaku Rantai Pasok}

a. Pemasok merupakan sumber yang menyediakan bahan pertama. Bahan pertama ini bisa dalam bentuk bahan baku, bahan mentah, bahan penolong, bahan dagangan, subassemblies, suku cadang, dan sebagainya.

b. Distribution atau barang sudah jadi yang dihasilkan oleh manufacturer sudah mulai harus disalurkan kepada pelanggan. Penyaluran barang dilakukan melalui distributor. Barang dari pabrik melalui gudangnya disalurkan ke gudang distributor atau wholesaler atau pedagang besar dalam jumlah besar.

c. Retail Outlets atau Pedagang besar biasanya mempunyai fasilitas gudang sendiri yang digunakan untuk menimbun barang sebelum disalurkan lagi ke pihak pengecer. Walaupun ada beberapa pabrik yang langsung menjual barang hasil produksinya kepada customer, namun secara relatif jumlahnya tidak banyak.

d. Customer merupakan rantai terakhir yang dilalui dalam supply chain. Para pengecer atau retailers ini menawarkan barangnya langsung kepada para pelanggan atau pembeli atau pengguna barang tersebut.

\section{Aliran Rantai Pasok}

a. Aliran barang yang mengalir dari hulu (upstream) ke hilir (downstream).

b. Aliran uang dan sejenisnya yang mengalir dari hilir ke hulu.

c. Aliran informasi yang bisa terjadi dari hulu ke hilir ataupun sebaliknya yang meliputi: i.Tahap pengelolaan permintaan.

Permintaan pelanggan menjadi acuan perusahaan untuk semua kegiatan pada PT. UNICOTIN. Tahap ini juga terkait dengan sistem order yang diterapkan oleh perusahaan.

ii Tahap persediaan bahan baku

a) Pemilihan pemasok bahan baku

b) Pengadaan bahan baku 
c) Pengiriman bahan baku dari pemasok hingga ke perusahaan

d) Pengendalian persediaan bahan baku

iii. Tahap Distribusi

a) Pemilihan jasa ekspedisi

b) Pengiriman produk

c) Memonitor pergerakan produk sampai kepada pelanggan

\section{Metode Analisis Data}

Teknik analisis data dalam penelitian ini menggunakan metode analisis deskriptif. Analisis deskriptif untuk mendeskripsikan keragaan rantai pasok pada PT. UNICOTIN.

\section{HASIL DAN PEMBAHASAN}

\section{Deskripsi PT. UNICOTIN}

PT. UNICOTIN didirikan pada tahun 1975 Oleh Bapak Jeffry Jocom, dan keluarga Jocom Besar. PT. UNICOTIN beralamat di Kelurahan Sarongsong Satu Kecamatan Airmadidi Kabupaten Minahasa Utara, Sulawesi Utara, Indonesia. Kantor Pusat berada di Jl. Lodan Raya 02 Blok T 01-02 Lodan Center, Jakarta Utara, Indonesia yang juga merupakan kantor pemasaran dengan pimpinan Mr. Riflex Manderos. PT. UNICOTIN khusus memproduksi "Desiccated Coconut" yang disebut juga tepung kelapa. Negara tujuan pemasaran produk ini adalah negara-negara Eropa Barat dan Timur, dan sebagian negara-negara di Afrika. Sasaran utama perdagangan adalah $100 \%$ ekspor. Dengan pengalaman yang sudah begitu banyak dalam memasok tepung kelapa ke luar negeri, dibawah pengendalian manajemen yang progresif, perusahaan ini terus mengupayakan kualitas dan kuantitas produksi yang lebih baik. PT. UNICOTIN merupakan salah satu dari pabrikpabrik yang ada di Sulawesi Utara dalam memproduksi tepung kelapa. Perusahaan ini diresmikan pada tahun 2007.

PT. UNICOTIN mempekerjakan 450 orang, termasuk pekerja borongan pada bagian shelling dan paring dengan waktu kerja selama 8 jam per hari dan memberlakukan sistem 3 shift kerja untuk bagian produksi, yaitu shift pagi (jam $6 \mathrm{~s} / \mathrm{d} 2$ siang) shift siang (jam 2 s/d jam 10 malam) dan shift malam (jam $10 \mathrm{~s} / \mathrm{d}$ jam 6 pagi).

\section{Deskripsi Produk Syarat bahan baku}

Pihak perusahaan memberikan informasi tentang standar kualitas kelapa yang digunakan untuk produksi, seperti berat standar biji kelapa minimal 650 gram, belum ada tunas, biji kelapa tidak muda, tidak busuk dan tidak pecah.

\section{Jenis Tepung Kelapa}

PT. UNICOTIN memproduksi tepung kelapa dengan 3 grade, yaitu, (1) Tepung Kelapa medium grade (Dessicated Coconut Medium Grade); (2) Tepung kelapa fine grade (Dessicated Coconut Fine Grade); (3) Tepung kelapa extra fine grade (Dessicated Coconut Extra Fine Grade). Tipe medium merupakan tipe yang paling banyak dipesan oleh industri makanan. Bentuk tepung kelapa berupa serbuk putih halus. Tepung kelapa yang sudah halus dengan berbagai jenis dikemas dengan standart kemasan yang ada agar dapat menjaga keamanan mutu tepung kelapa.

\section{Kandungan Tepung Kelapa}

Nutrisi yang terkandung dalam tepung kelapa 120 kalori. 18gram karbohidrat. 10 gram serat. 6gram protein.

\section{Manfaat Tepung Kelapa}

Tepung kelapa memiliki banyak manfaat untuk kesehatan seperti:

1. Mengendalikan gula darah karena tepung kelapa mengandung serat yang tinggi, tepung ini dapat mengontrol gula darah Anda.

2. Menurunkan berat badan.

3. Membantu metabolisme.

4. Membantu kesehatan pencernaan.

Di Negara yang beriklim empat musim banyak dibutuhkan karena pada musim dingin, tepung kelapa merupakan sumber energi yang tinggi.

\section{Proses Produksi Tepung Kelapa Di PT. UNICOTIN}

Alur produksi produk turunan kelapa ini tergambar dalam diagram berikut ini. 


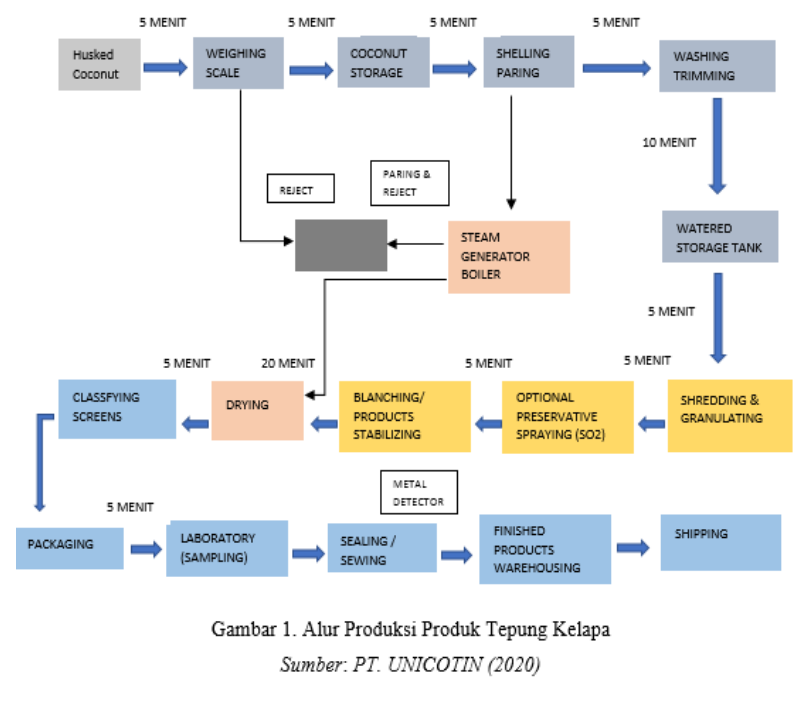

Lamanya waktu yang dibutuhkan untuk proses produksi kelapa adalah \pm 1 jam. Alur produksi tepung kelapa di PT. UNICOTIN bermula dari husked coconut (buah kelapa yang sudah dikupas) diangkut oleh pemasok ke pabrik. Selanjutnya kelapa ini ditimbang di weighing scale/jembatan timbang untuk menimbang berat bersih hingga kelapa yang di reject. Setelah itu kelapa tersebut dibawa ke tempat penyimpanan kelapa sementara yang mana ditempat ini kelapa tersebut disortir yang mana yang akan digunakan. Setelah proses penyortiran selesai, batok kelapa dibersihkan dari tempurung kemudian pemisahan antara daging kelapa dengan kulit arinya (paring). Proses selanjutnya adalah washing trimming, yaitu tempat untuk pencucian daging buah kelapa tersebut untuk memisahkan serabut-serabut yang menempel pada daging kelapa, lalu buah kelapa ini direndam terlebih dahulu di watered storage tank sebelum dihancurkan/digiling menjadi butiran halus pada proses shreading \& granulating. Buah kelapa yang telah digiling/diparut ini kemudian ditambahkan bahan pengawet pada proses Optional Preservative Spraying (yang mana bagian ini merupakan bagian yang hanya jika dibutuhkan/permintaan pelanggan). Setelah itu masuk pada proses blanching/products stabilizing, yang mana proses ini bertujuan untuk mempertahankan warna putih alami dari tepung kelapa. Setelah itu masuk pada proses drying, yaitu memanaskan dan mengeringkan tepung kelapa. Proses selanjutnya adalah classifying screens, yaitu mengayak tepung kelapa ini dan mengklasifikasikannya sesuai ukuran butiran. Setelah itu tepung kelapa ini masuk dalam proses packaging (pengepakan). Sebelum disegel/dijahit pengepakan ini, diambil terlebih dahulu sampel-sampel untuk diuji di laboratorium selama 1 hari, setelah dinyatakan bersih barulah produk ini siap untuk dikirimkan/diekspor. Pengiriman ini dilakukan dengan jasa ekspedisi ke luar negeri.

\section{Keragaan Rantai Pasok Tepung Kelapa PT. UNICOTIN}

Berdasarkan hasil identifikasi, keragaan rantai pasok tepung kelapa yang dikelola oleh PT. UNICOTIN dimulai dari pemasok bahan baku, PT. UNICOTIN dan pelanggan, yang dapat diidentifikasi sebagai pelaku rantai pasok adalah sebagai berikut:

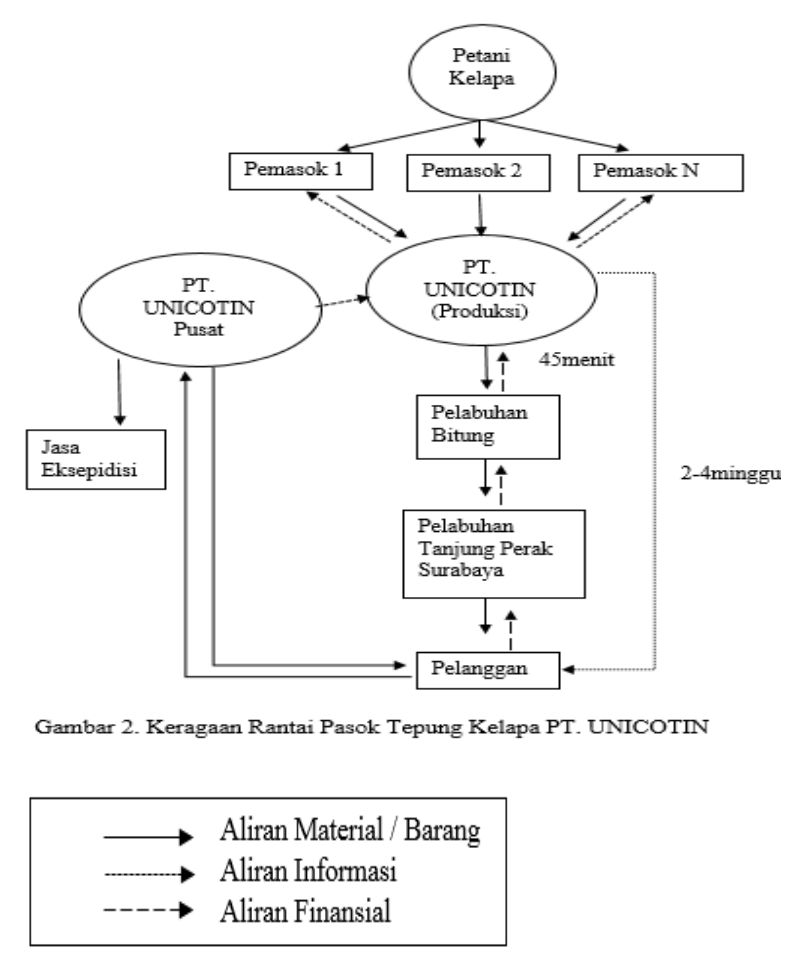

\section{Pelaku Rantai Pasok}

a. Pemasok bahan baku (supplier), bahan baku berasal dari beberapa daerah di Kabupaten Minahasa Utara yaitu, Desa Airmadidi, Desa Kamanta, Desa Silian, Desa Tumaluntung, Desa Lembean, Desa Kolongan, Desa Klabat, Desa Treman, 
Adapun kecamatan Amurang dan kabupaten Bolaang Mongondow. Bahan baku kelapa dipasok setiap hari dan kuantitas pasokan tergantung pada kemampuan masingmasing pemasok.

b. Pabrik (manufacturer) yaitu, pabrik PT. UNICOTIN terletak di Minahasa Utara, Sulawesi Utara. PT. UNICOTIN memiliki dua lokasi yang berbeda, kantor pusat PT. UNICOTIN terletak di Jakarta yang menangani bagian keuangan serta kegiatan pemasaran, pembelian dan pengiriman. Sedangkan pabrik PT. UNICOTIN terletak di Minahasa Utara yang khusus menangani bagian produksi tepung kelapa. Pelanggan melakukan pemesanan dengan bagian marketing di kantor pusat.

c. Distributor yaitu, Jasa Ekspedisi yang berada di pelabuhan Bitung dan pelabuhan Tanjung Perak di Surabaya.

d. Pelanggan (customer), merupakan mata rantai terakhir dari rantai pasok tepung kelapa PT. UNICOTIN yaitu, negara Jerman, Belanda, Inggris, Polandia, Mesir, Rusia dan Cina.

\section{Peran Pelaku Rantai Pasok}

a. Pemasok merupakan sumber yang menyediakan bahan pertama. Bahan baku kelapa dari berbagai daerah yang tersebar di Sulawesi Utara, seperti Kabupaten Minahasa Utara, Kabupaten Minahasa Selatan dan Kabupaten Bolaang Mongondow. Peran dari pemasok adalah menyediakan bahan baku kelapa butir untuk diproses menjadi tepung kelapa.

b. PT. UNICOTIN yang mengolah daging buah kelapa menjadi produk setengah jadi yaitu, tepung kelapa dalam beberapa jenis yang dibedakan menjadi 3 tipe yaitu fine, medium dan extra fine. Hasil tepung kelapa menciptakan nilai tambah sehingga dapat dipasarkan secara ekspor ke beberapa Negara Eropa dan Asia. Dengan memproduksi tepung kelapa ini pun memberikan peran yang baik dalam membantu mengurangi resiko dalam komoditi kelapa yaitu buah kelapa yang mudah rusak dimanfaatkan menjadi produk yang memiliki mutu serta kualitas yang tinggi dipasar internasional. Dengan demikian PT. UNICOTIN berperan menciptakan nilai tambah. c. Distributor yang merupakan penyalur barang yang sudah jadi yang dihasilkan oleh pabrik dilakukan melalui jasa ekspedisi yang berperan dalam proses pengiriman produk dari PT. UNICOTIN hingga kepada konsumen. Pengiriman tepung kelapa melalui pelabuhan Bitung dan dilanjutkan ke pelabuhan Tanjung Perak di Surabaya untuk dikirim ke berbagai Negara tujuan ekspor. Dalam hal ini peran distributor adalah mendistribusikan tepung kelapa mulai dari Pabrikan ke Pelabuhan Bitung selanjutnya ke Pelabuhan Tanjung Perak Surabaya untuk kemudian dikirim ke luar negeri.

d. Customer (pelanggan) dalam penelitian ini adalah pembeli atau pengguna barang yang berasal dari berbagai negara yakni, Jerman, Belanda, Inggris, Polandia, Mesir, Rusia dan Cina. Pelanggan berperan juga dalam memberikan peningkatan penerimaan hasil dalam nilai finansial terhadap pabrik.

\section{Aliran Rantai Pasok PT. UNICOTIN Aliran Informasi}

a. Tahap pengelolaan permintaan

Perusahaan menganut pull-based system dimana kegiatan produksi maupun distribusi produk didasarkan atas permintaan konsumen, bukan melalui peramalan. Namun, perusahaan tidak selalu menjalankan kegiatan produksi berdasarkan permintaan, karena dalam sekali produksi dapat menghasilkan tiga tipe tepung kelapa. Kondisi saat ini, perusahaan harus menyeimbangkan antara jumlah permintaan dengan kapasitas produksi sehingga perusahaan tidak menerima semua permintaan yang ada.

b. Tahap pengadaan bahan baku

Dalam hal memilih pemasok bahan baku, PT. UNICOTIN melakukan wawancara terlebih dahulu untuk mengetahui informasi tentang pemasok, seperti keadaan lokasi dan gudang untuk bahan baku, kapasitas kelapa yang dapat dikirim pemasok, serta orang-orang yang dipekerjakan. 
Setelah pihak perusahaan dan pemasok mencapai bentuk kerjasama yang disepakati bersama, maka pemasok dapat memasok kelapa ke pabrik PT. UNICOTIN dan kuantitas kelapa yang dikirim sesuai dengan kemampuan pemasok. Setiap hari, perusahaan menerima pasokan bahan baku dari beberapa pemasok yang mempunyai persediaan bahan baku untuk memenuhi kebutuhan produksi tepung kelapa sebesar 250.000 kilogram dalam sekali produksi. Pemasok yang sudah siap, langsung mengirim bahan baku dari lokasinya ke pabrik menggunakan truk milik perusahaan atau milik pemasok, jika ada.

Setiap tahun, perusahaan membentuk beberapa tim dalam rangka mengunjungi setiap pemasok untuk menjaga relasi yang baik. Selain itu, kegiatan kunjungan tersebut bertujuan untuk menjelaskan kembali kepada pemasok tentang kualitas bahan baku yang diterima perusahaan, meninjau kembali lokasi bahan baku agar jauh dari area pertambangan, gudang penyimpanan kelapa harus bersih dan jauh dari kandang hewan.

Naiknya harga beli kelapa disebabkan oleh musim kemarau panjang yang terjadi pada tahun 2019 dan mengakibatkan produktivitas serta kualitas dari kelapa menurun. Selain itu, akibat dari turunnya produktivitas dan kualitas kelapa yang dihasilkan tahun ini, perusahaan harus menunggu 2 sampai 3 hari agar stok bahan baku dapat tercapai untuk memenuhi kebutuhan sebanyak 250.000 kilogram / 250 ton per hari. Bahan baku disimpan dalam tempat penyimpanan khusus kelapa sampai stok bahan baku terpenuhi. Persaingan antar perusahaan sejenis juga berpengaruh pada proses pengadaan bahan baku perusahaan.

Sulawesi Utara terdapat 9 perusahaan yang memproduksi tepung kelapa, sehingga satu pemasok kelapa tidak hanya memasok bahan baku ke satu perusahaan saja tetapi ke beberapa perusahaan lainnya. Beberapa pemaosk terkadang memprioritaskan perusahaan yang penawarannya lebih tinggi dari segi kuantitas pemesanan dan harga yang disepakati.

\section{c. Tahap Distribusi}

Setelah tepung Kelapa dinyatakan siap untuk diekspor, maka manager pabrik akan memberikan informasi kepada bagian marketing dan diteruskan kepada bagian shipping yang berada di kantor pusat untuk ditindak lanjuti. Tepung kelapa akan diangkut menggunakan container untuk dibawa ke pelabuhan Bitung. Dikatakan bahwa setiap hari perusahaan melakukan pengiriman 1 container yang berisi 1.040bags. Perusahaan dalam menjadwalkan pengiriman menyesuaikan dengan jadwal kapal yang akan berangkat untuk mencegah penumpukan di pelabuhan. Jarak antara pabrik dengan pelabuhan Bitung yang cukup jauh yang memakan waktu sekitar 45 menit, menjadi pertimbangan perusahaan dalam hal mengirim produk. Sehingga perusahaan perlu tahu informasi untuk jadwal keberangkatan kapal secara akurat agar tidak terjadi keterlambatan.

Pemilihan jasa ekspedisi oleh perusahaan tidak mempunyai kriteria maupun kerjasama yang khusus dengan jasa ekspedisi tertentu. Jadi, pada saat akan melakukan pengiriman, perusahaan menggunakan jasa ekspedisi yang sudah siap untuk pengiriman. Setelah perusahaan mendapatkan jasa ekspedisi yang sudah siap dan telah membayar biaya pengirimannya maka produk akan di angkut dari pabrik menggunakan container menuju pelabuhan Bitung. Selanjutnya, produk akan dimuat ke dalam kapal dan dikirim menuju pelabuhan Surabaya untuk diperiksa dan diekspor ke berbagai Negara tujuan. Selain produk, dokumen-dokumen yang diperlukan juga dikirim kepada konsumen seperti invoice, pemberitahuan ekspor barang (PEB), Surat keterangan asal barang, dan sertifikat Phytosanitary. Waktu rata-rata yang dibutuhkan untuk mengirim produk kepada konsumen adalah 2-4 minggu tergantung jaraknya. Perusahaan juga memonitor pergerakan produk untuk memastikan produk sampai ke tangan konsumen dengan tepat waktu. Perusahaan akan menerima laporan dari jasa ekspedisi secara online, seperti informasi produk sudah sampai dimana dan siapa yang menerima produk tersebut. 


\section{Aliran Produk}

PT. UNICOTIN menerima pasokan bahan baku kelapa dari petani, petani yang merangkap, pedagang pengumpul, dari berbagai daerah yang tersebar di Sulawesi Utara, seperti Minahasa Utara, Minahasa Selatan dan Bolaang Mongondow. Waktu yang dibutuhkan untuk pemasok dari Minut 3 Jam, sedangkan dari Minahasa 5 jam, dan dari Bolaang Mongondow 36 Jam. Harga pembelian bahan baku kelapa saat ini berkisar antara Rp. 2.100-Rp. 2.200 per kilogram. Aliran produk dapat digambarkan sebagai berikut:

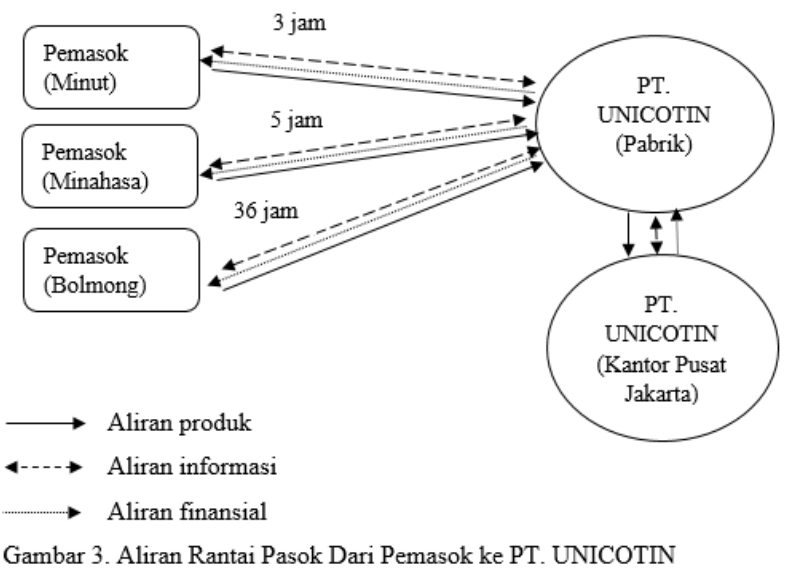

Waktu yang diperlukan untuk melakukan pengiriman bahan baku tergantung pada jarak antara lokasi bahan baku dan pabrik. Dalam hal ini, terdapat juga pemasok yang tidak tepat waktu dalam mengirim bahan baku ke pabrik. Pemasok yang berasal dari Minahasa Utara ada 5 Desa yaitu, Tumaluntung, Lembean, Kolongan, Klabat dan Treman. Berdasarkan harga pasar di Minahasa Utara sekitar Rp2.100 per buah kelapa tanpa sabut atau yang sudah dikupas kulit luarnya. Pemasok yang berada di Minahasa Utara:

1. Pemasok yang berasal dari Desa Lembean yang mengumpulkan buah kelapa yang belum dikupas dari kebun petani kelapa dengan harga Rp1.250/buah dengan membiayai pekerja 5-6orang sekali panen dalam berbagai bagian kerja yaitu, memanjat pohon kelapa sebesar Rp5.000 per pohon, pekerja yang mengupas kelapa dibiayai Rp150/buah, mengumpulkan Rp50/buah, memikul atau mengangkat menggunakan gerobak \pm 100 meter dibiayai sebesar Rp100 Rp200/buah. Jarak tempuh \pm 1 jam buah kelapa biasanya dibawa ke pabrik 3-4kali dalam seminggu sebanyak 1.000 buah kelapa dengan harga Rp2.000/kg.

2. Pemasok yang berasal dari Desa Treman adalah seorang petani kelapa yang memiliki luas lahan perkebunan 100 hektar dengan berbagai tanaman lain yaitu, pala, cengkeh, kelapa serta ladang. Pemasok pun mempekerjakan 6 orang untuk memanjat dengan upah Rp5.000 per pohon, mengupas kelapa Rp100/buah dan mengangkut Rp100/buah. Dalam jangka waktu pengiriman \pm 1 jam dari Desa Treman ke pabrik. Pemasok mengirim hasil panen 5ton buah kelapa setiap minggu dengan harga jual Rp2.200/kg.

3. Pemasok dari Klabat merupakan petani sekaligus pemasok yang selain memiliki luas lahan kelapa 3 hektar untuk dipanen juga membeli bahan baku kelapa dari 15 pemasok kira-kira sebanyak 100 ton per bulan. Pemasok pun mempekerjakan 3 orang untuk mengangkut buah kelapa dengan upah Rp150/buah. Dalam jangka waktu 1 jam pemasok sudah bisa membawa 1600 -1700 kelapa ke pabrik dengan harga Rp2.200/buah

Kapasitas produksi untuk tahun ini berkisar 230 sampai 250 ton per hari, jika bahan baku kelapa melimpah dapat mencapai 300 ton per hari. Setelah bahan baku kelapa sampai ke lokasi pabrik, truk beserta isinya akan berhenti pada jalur timbangan untuk ditimbang secara otomatis yang akan menunjukkan berat dan tercetak dalam formulir. Selanjutnya, truk menuju tempat penampungan kelapa untuk dibongkar dan disortir mutunya agar mendapatkan kualitas kelapa yang sesuai dengan standar yang dibutuhkan. Kapasitas produksi tepung kelapa 1.000 kilogram per jam. Sekitar $5.000-8.000$ biji kelapa yang dibutuhkan untuk di produksi per jam.

\section{Aliran Finansial}

Konsumen yang berada di luar negeri melakukan pemesanan melalui e-mail, dengan cara forward booking. Setelah proses pemesanan selesai, bagian marketing di kantor pusat Jakarta memberikan informasi kepada manager pabrik tentang jenis tepung yang dipesan, kuantitas yang akan dikirim, dan waktu 
pengiriman yang telah disepakati. Selanjutnya Pabrik mengadakan Pembelian bahan baku kelapa dilakukan oleh bagian Nuts Buying yang berada di kantor pusat PT. UNICOTIN. Ada 2 sistem pembayaran yakni, (1) pelanggan harus membayar terlebih dahulu 30\% sementara dokumen disiapkan oleh pabrik untuk dikirim kepada pelanggan sebagai catatan pemesanan dan setelah dokumen telah siap dan dikirim maka pelanggan langsung membayar sisa jumlah $70 \%$ yang telah disepakati dengan pihak perusahaan, (2) adapun semua dokumen pengiriman selesai dan dikirimkan ke pembeli yang merupakan pelanggan dan pelanggan langsung membayar biaya sesuai dokumen pengiriman. Pada dokumen telah tertera harga, jenis barang, berat barang, nama pelanggan, tujuan dan nomor invoice.

\begin{tabular}{|c|c|c|c|}
\hline \multicolumn{3}{|c|}{ Hulu/upstream } & Hilir/Downstream \\
\hline Pemasok & Pabrik & Kantor Pusat & Pelanggan \\
\hline
\end{tabular}

Gambar 4. Aliran Finansial

\section{KESIMPULAN DAN SARAN}

\section{Kesimpulan}

1. Pelaku rantai pasok adalah (a) Pemasok bahan baku kelapa meliputi petani, petani yang merangkap, pedagang pengumpul, (b) PT. UNICOTIN di Airmadidi, (c) Kantor pusat PT. UNICOTIN di Jakarta, (d) importir besar di Jerman, Belanda, Inggris, Polandia, Mesir, Rusia dan Cina, dan importir lainnya dalam jumlah kecil

2. Peran pelaku rantai pasok dari Tepung kelapa adalah (a) pemasok memenuhi permintaan bahan baku daging kelapa dalam bentuk kelapa butiran, (b) PT. UNICOTIN di Airmadidi mengolah daging buah kelapa menjadi tepung kelapa dan penciptaan nilai tambah, mengirim tepung kelapa ke pelabuhan Tanjung Perak (c) PT. UNICOTIN sebagai distributor di Jakarta juga menangani bagian keuangan serta kegiatan pemasaran dan pengiriman dari Indonesia ke negara tujuan yaitu, negara Jerman, Belanda, Inggris, Polandia, Mesir, Rusia dan Cina, juga negara lain dalam jumlah kecil, (d) Importir sebagai pelanggan di PT. UNICOTIN dan merupakan distributor di negaranya

3. Aliran rantai pasok terdiri dari:

(a) Aliran informasi berawal dari kebutuhan tepung kelapa dari importir ke Kantor Pusat Jakarta, kemudian kebutuhan tersebut akan dipenuhi oleh Pabrik tepung kelapa kemudian ke pemasok bahan baku yang terdiri dari petani, petani yang merangkap dan pedagang penumpul dan sebaliknya

(b) Aliran produk diawali dari persediaan bahan baku kelapa dari pemasok yang terdiri dari petani, petani yang merangkap, pedagang pengumpul, dari berbagai daerah yang tersebar di Sulawesi Utara ke Pabrik tepung kelapa PT. UNICOTIN, Daging kelapa yang sudah diolah menjadi tepung kelapa dikirim ke Surabaya sebagai tempat mengeksport tepung kelapa atas koordinasi Kantor Pusat Jakarta ke Negara tujuan dan konsumen akhir.

(c) Aliran finansial berupa pembayaran Importir ke kantor pusat Jakarta yang kemudian ke pabrik tepung kelapa PT. UNICOTIN yang digunakan untuk operasional pabrik dan pembelian bahan baku kelapa butir.

\section{Saran}

Perusahaan perlu menemukan solusi untuk pemasok yang tidak konsisten dalam hal prioritas untuk memasok bahan baku ke PT. UNICOTIN agar pihak perusahaan dapat memenuhi kebutuhan bahan bakunya dengan tepat waktu dan perusahaan juga perlu menjalin kerjasama dengan jasa ekspedisi yang terpilih untuk jangka panjang, agar informasi tentang jadwal keberangkatan kapal lebih akurat dan informasi tentang pengiriman produk lebih lancar. 


\section{DAFTAR PUSTAKA}

Anonimous, 2013. Penelitian Pabrik Tepung Kelapa.

http://agussupu.wordpress.com/tag/pen elitian-pabrik-tepung-kelapa (diakses September 2020).

Assauri, S. 2011. Manajemen Produksi dan Operasi. Lembaga Penerbit FEUI. Jakarta.
Levi, David, and S. Levi. 2003. Desinging and Managing The Supply Chain: Concept, Strategies and Case Studies. Irwin McGraw-Hill, Singapore.

Porter. 2004. E-Business Supply Chain Managemenet. STIMIK AMIKOM. Yogyakarta. 